\title{
Artificial tritrophic exposure system for environmental risk analysis on aphidophagous predators
}

\author{
DÉBORA P. PAULA ${ }^{1}$, LUCAS M. DE SOUZA ${ }^{1}$, DAVID A. ANDOW ${ }^{2}$, ALEX A.T. \\ CORTÊS DE SOUSA ${ }^{1}$, CARMEN S.S. PIRES ${ }^{1}$ and EDISON R. SUJII ${ }^{1}$ \\ ${ }^{1}$ Embrapa Genetic Resources and Biotechnology, Parque Estação Biológica, \\ Avenida W5 Norte (final), 70770-917 Brasília, DF, Brasil \\ ${ }^{2}$ Department of Entomology, University of Minnesota, 219 Hodson Hall, 1980 Folwell Ave., St. Paul, MN, 55108, USA \\ Manuscript received on December 11, 2015; accepted for publication on March 18, 2016
}

\begin{abstract}
We evaluated an artificial tritrophic exposure system for use in ecotoxicological evaluations of environmental stressors on aphidophagous predators. It consists of an acrylic tube with a Parafilm M sachet containing liquid aphid diet, into which can be added environmental stressors. Immature Cycloneda sanguinea, Harmonia axyridis and Chrysoperla externa, and adult H. axyridis were reared on Myzus persicae. Larval and pupal development and survival of all species and reproductive parameters of $H$. axyridis were similar to published results. The system provides a suitable tritrophic exposure route, enables ex-ante evaluation of stressors, and improves the accuracy of the assessment.
\end{abstract}

Key words: beneficial insects, biosafety, ecotoxicology, exposure routes.

\section{INTRODUCTION}

Insect non-target predators can be exposed to environmental stressors, such as $B t$ entomotoxins in genetically modified (GM) plants, directly by consumption of parts of the GM plant or indirectly by predation on herbivores that themselves had fed on a GM plant (Groot and Dicke 2002, Romeis et al. 2006, Lövei et al. 2009). An ecotoxicological evaluation of effects on predators is often made by: a) exposing them to GM plant parts (such as pollen) or to an herbivore that fed on the GM plant, or b) by inoculating (or spraying) an environmental

Correspondence to: Débora Pires Paula

E-mail: debora.pires@embrapa.br stressor on artificial diets or on predator food. In the first case, the environmental risk assessment is constrained to occur after the development of the technological product (e.g. GM plant) containing the environmental stressor, and in the second case, by the power of the ecological inferences that can be made using artificial exposure routes that do not fully simulate nature exposure. In this work we present a practical system that can be used to make an ex-ante ecotoxicological analysis of environmental stressors on aphidophagous predators through an ecologically relevant tritrophic exposure. We evaluate its practicality using three common generalist predator species that feed on pest aphid species. 


\section{MATERIALS AND METHODS}

PREPARATION OF THE SYSTEM

The system (Douglas and van Emden, 2007) was made with transparent acrylic tubes $(2.5 \mathrm{~cm}$ diameter x $2.5 \mathrm{~cm}$ height, wall thickness $0.35 \mathrm{~cm}$ ) with two layers of parafilm $\mathrm{M}$ on one end forming a sachet, inside of which was 150 to $500 \mu 1$ of liquid diet for rearing aphids (Dadd and Mittler 1966). Each tube required two square pieces of parafilm (Fig. 1a). One parafilm piece was stretched in both directions and attached to one end of the tube (Fig. 1b). The tube with the parafilm attached and the second piece of parafilm were sterilized by UV

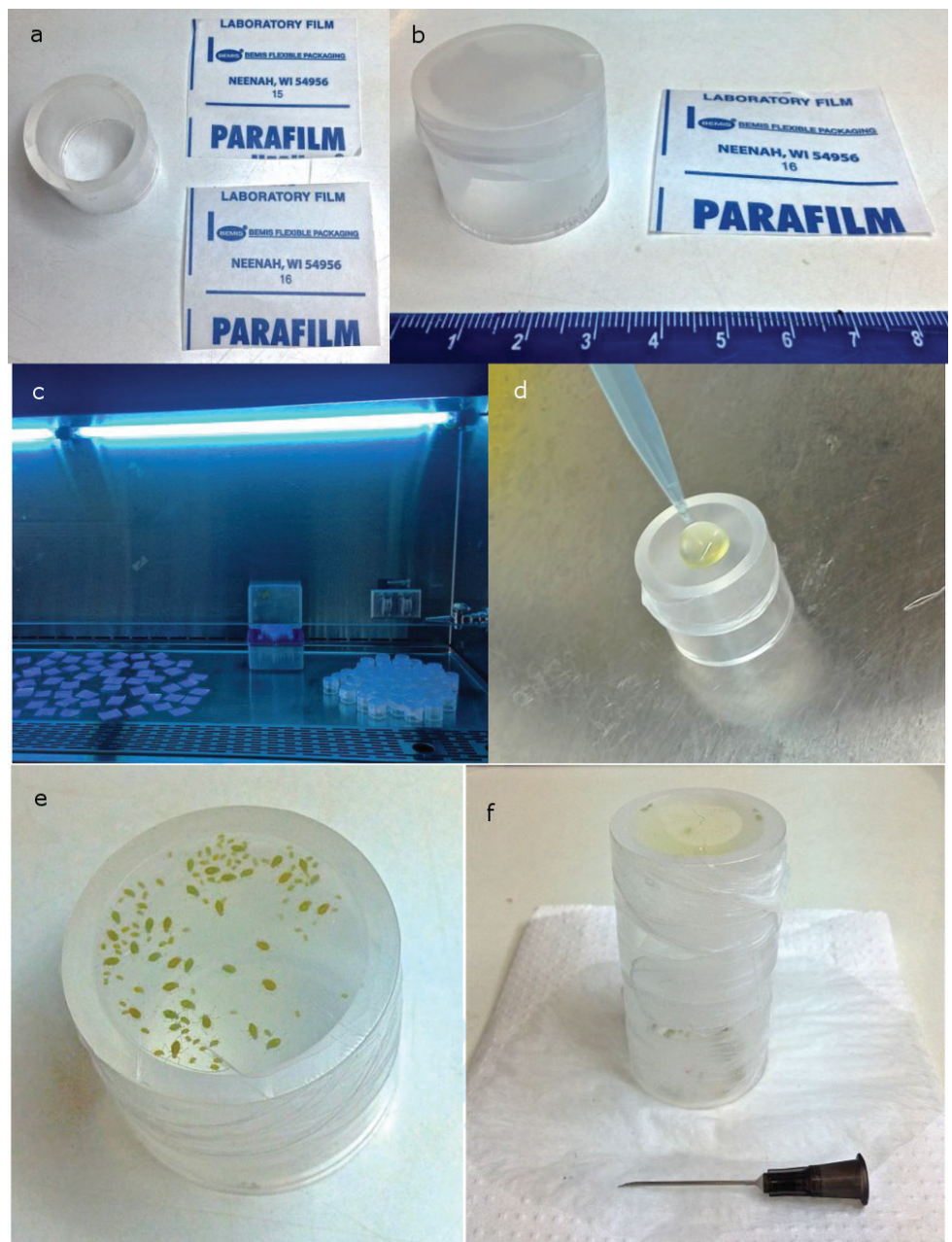

Figure 1 - Artificial tritrophic system for rearing aphids and aphidophagous predators: a) Tube and two Parafilm M pieces; b) Tube with one parafilm layer attached and a second parafilm piece, ruler with scale in $\mathrm{cm}$; $\mathbf{c}$ ) Sterilization of the system components by UV irradiation in a laminar flow hood; d) Pipetting of the diet onto the parafilm layer attached to the tube; e) Completed artificial aphid feeding system containing M. persicae feeding from the lower parafilm layer inside the tube; f) Aphid transfer to a tube with new diet. First the old and new tube are coupled together using a parafilm strip, then the diet is drained from the old tube by making holes with a needle and putting it upside down on absorbent paper. The aphids move from the old tube to the new one. 
radiation for 30 to $40 \mathrm{~min}$ in a laminar flow hood (Fig. 1c). The liquid diet was sterilized by filtration using a filter (pore size of $0.22 \mu \mathrm{m}$ ) coupled to a plastic syringe in a laminar flow hood. The feeding tubes were finished inside a laminar flow hood by pipetting (with sterilized tips) the filtered diet on the sterilized layer of parafilm attached to the tube (Fig. 1d), and covering it with the sterilized face of the second parafilm piece, after stretching it in both directions. When the tubes were finished, $M$. persicae aphids were carefully transferred into them using a paint-brush (\#2).

REARINGPREDATORSINTHEARTIFICIALTRITROPHICSYSTEM

Green peach aphid, Myzus persicae (Hemiptera: Aphididae), and the predaceous ladybird beetles, Cycloneda sanguinea and Harmonia axyridis (Coleoptera: Coccinellidae), and green lacewing, Chrysoperla externa (Neuroptera: Chrysopidae), were obtained from laboratory colonies and reared in growth chambers at $25 \pm 2^{\circ} \mathrm{C}$ and 16:8 LD, based on Paula et al. (2015) and Carvalho and Souza (2009). Unfed, recently emerged $(<24 \mathrm{~h})$ coccinellid and chrysopid neonates were individually (10 replicates each species) transferred to the system containing M. persicae aphids that had fed on the diet for at least $24 \mathrm{~h}$ and reared in a growth chamber at $25 \pm 2^{\circ} \mathrm{C}$ and 16:8 LD. The predator larvae were transferred daily to new tubes containing aphids feeding on the diet. Development time and survival (larval and pupal) were measured. Recently emerged adults $(<24 \mathrm{~h})$ were individually weighed and sexed. In addition, unfed recently $(<24 \mathrm{~h})$ emerged $H$. axyridis couples $(n \geq 10)$ were individually transferred to the system containing $100 \mathrm{M}$. persicae aphids and reared for 20 days, as mentioned previously. The number of eggs laid and egg development time were recorded. Comparisons between our experimental values and published values were made using Welch's $t$-test (assuming unequal sample size and unequal variance) with a Bonferroni correction for the $P$-value when there were multiple comparisons.

\section{RESULTS AND DISCUSSION}

Overall the system provided suitable conditions for rearing the predator species (Tables I to III). Although we noted many differences in the biological parameter values compared to published values, there were no consistent differences, indicating that the performance of the predators in the system was within the normal range of variation of other rearing systems. Therefore, the system can be used in ecotoxicological tests as a tritrophic route of exposure for aphidophagous predators to several kinds of environmental stressors that can be added directly in the aphid diet, such as Bt proteins (Paula et al. 2015), dsRNAi and entomopathogenic agents (e.g., bacteria).

The main advantages of using this system are a) independence of the aphid from its host plant, enabling evaluation of an environmental stressor early in the development of a GM plant, and b) control of the exposure of the environmental stressor, in terms of concentration, homogeneity and constancy over time. In the first case, early ecotoxicological tests can provide a basis to optimize an intended technology (e.g., to produce an entomotoxin that is more species-specific) or even support the decision making process of continuing investments in development or not. In the second case, the control of exposure of an environmental stressor has fundamental relevance to risk analysis as it provides higher accuracy and precision in the estimation of potential effects by reducing extraneous sources of variability within and across treatments, thereby reducing residual error caused by varied expression of the stressor in the GM plant in response to the environment conditions, tissue type, developmental stage, or difference in variety/cultivar (genetic background) (Hilbeck et al. 2006; Romeis et al. 2008). 


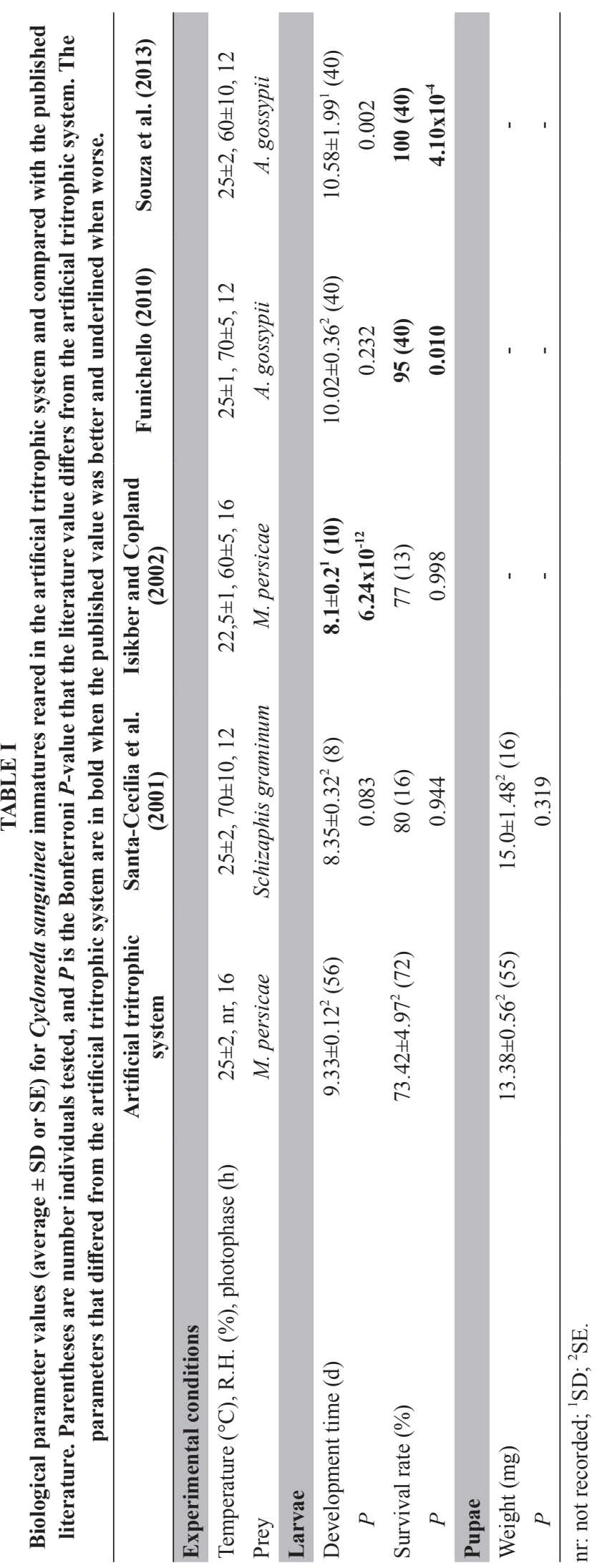




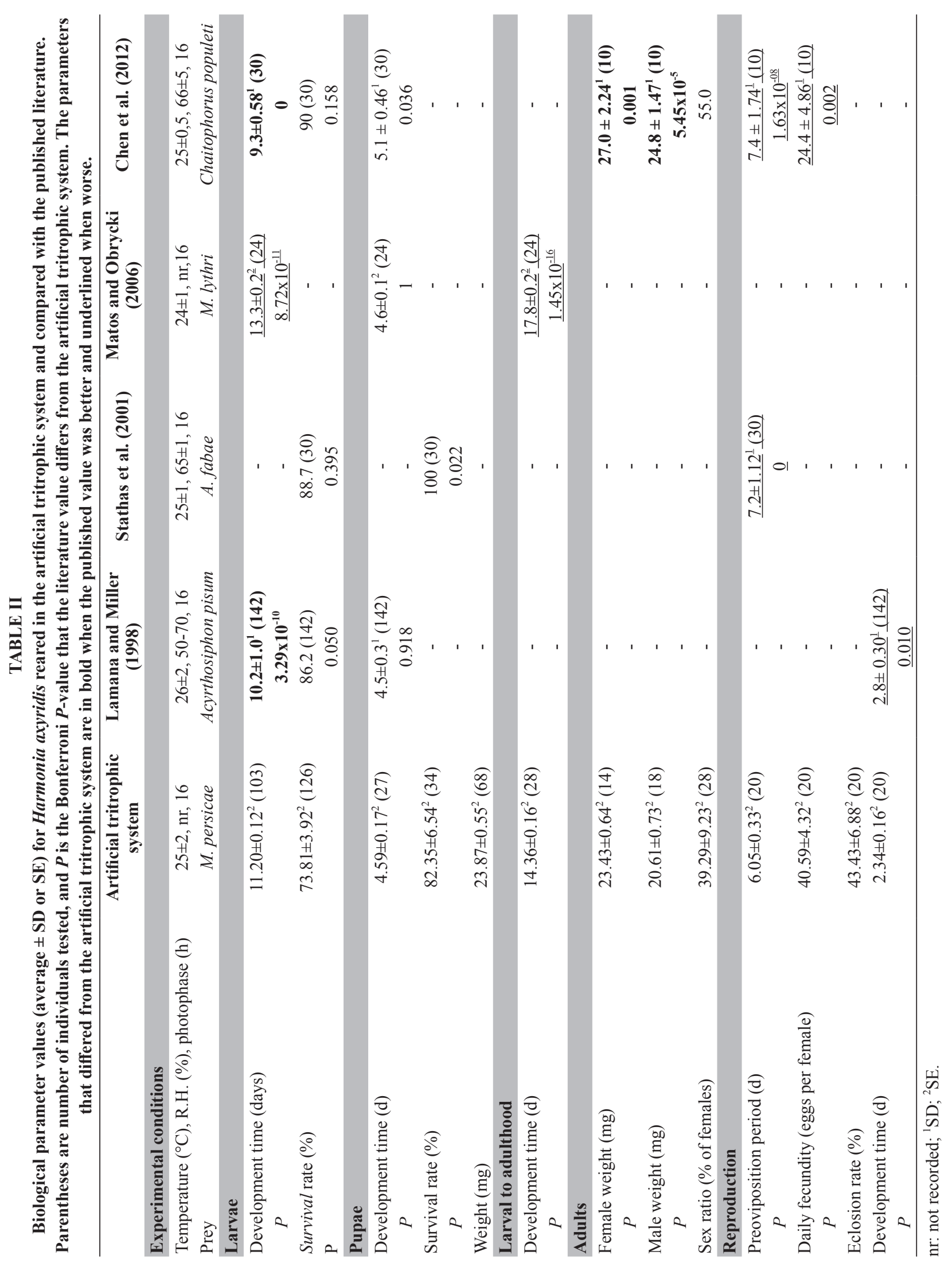


DÉBORA P. PAULA et al.

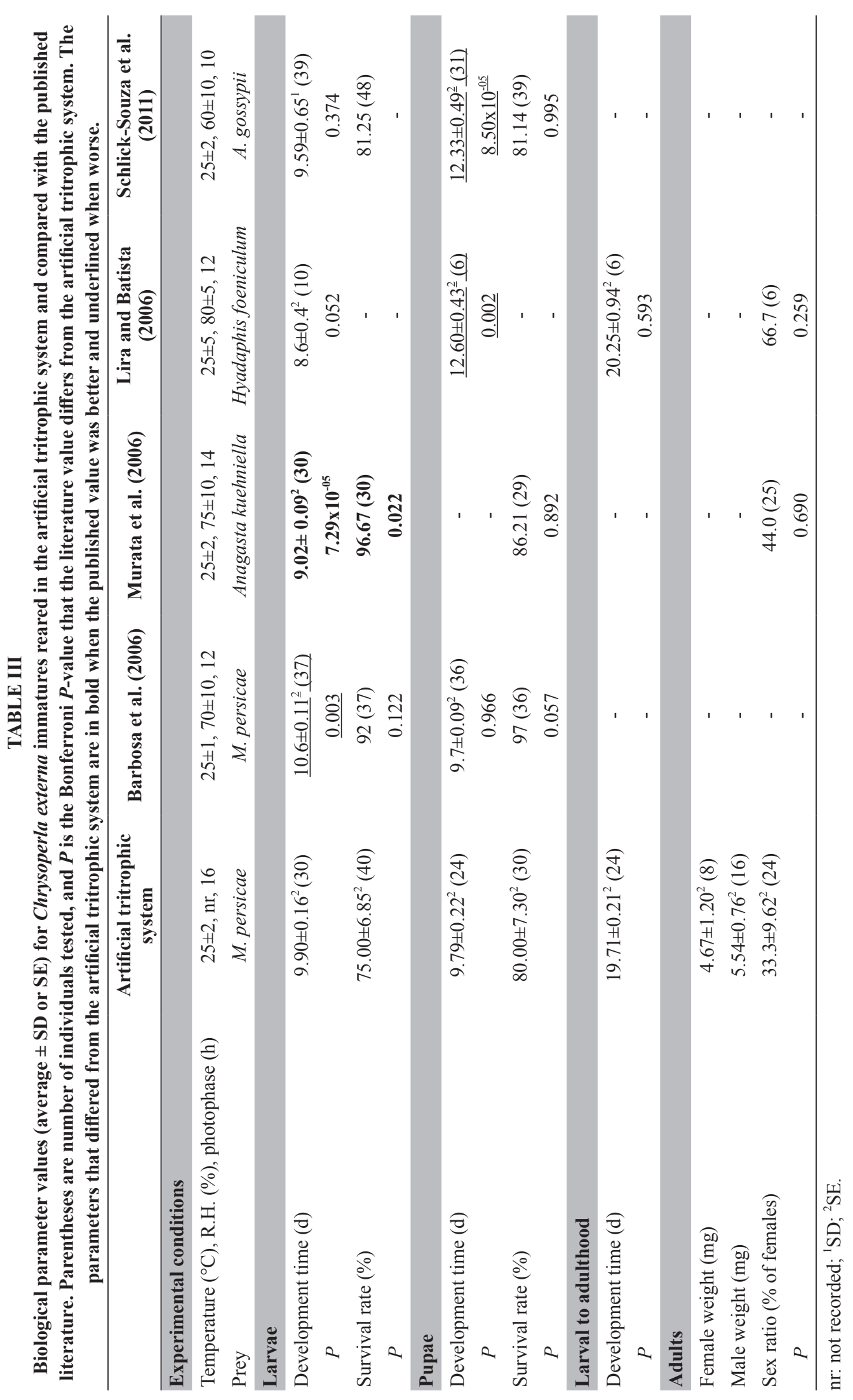




\section{ACKNOWLEDGMENTS}

We thank Bruna Lima for preparing the diet and artificial system and collecting aphids from the field; Dr. Brígida de Souza, Elaine Louzada and Jander Souza from the Universidade Federal de Lavras for providing the Ch. externa to rear at Embrapa Cenargen; and Juã Pereira for permitting the collection of $M$. persicae from his farm.

\section{REFERENCES}

BARBOSA LR, CARVALHO CF, SOUZA B AND AUAD AM. 2006. Influência da densidade de Myzus persicae (Sulzer) sobre alguns aspectos biológicos e capacidade predatória de Chrysoperla externa (Hagen). Acta Sci Agron 28(2): 227-231.

CARVALHO CF AND SOUZA B. 2009. Métodos de criação e produção de crisopídeos. In: Controle biológico de pragas, produção massal e controle de qualidade. Bueno VHP, Editora UFL, Lavras-MG, p. 77-115.

CHEN J, QIN QJ, LIU S AND HE YZ. 2012. Effect of six diets on development and fecundity of Harmonia axyridis (Pallas) (Coleoptera: Coccinellidae). African Entomology 20(1): 85-90.

DADD RH AND MITTLER TE. 1966. Permanent culture of an aphid on a totally synthetic diet. Experientia 22: 832-833.

DOUGLAS AE AND VAN EMDEN HF. 2007. Nutrition and Symbiosis. Chapter 5. In: Van Emden HF and Harrington $\mathrm{R}$ (Eds), Aphis as crop pests. p. 105-134.

FUNICHELLO M. 2010. Aspectos biológicos de Cycloneda sanguinea (L.) (Coleoptera: Coccinellidae) e de Aphis gossypii Glover (Hemiptera: Aphididae), criados nas cultivares Deltaopal e Nuopal (Bollgard I). Dissertação de mestrado, UNESP, Fac. Ciências Agrárias e Veterinárias, 56 p. (Unpublished).

GROOT AT AND DICKE M. 2002. Insect-resistant transgenic plants in a multi-trophic context. Plant J 31: 387-406.

HILBECK A, ANDOW DA, ARPAIA S, BIRCH ANE, FONTES EMG, LÖVEI GL, SUJII ER, WHEATLEY RE AND UNDERWOOD E. 2006. Methodology to support non-target and biodiversity risk assessment. In: Environmental risk assessment of genetically modified organisms, methodologies for assessing Bt cotton in Brazil. Chapter 5. Edited by Hilbeck A, Andow DA and Fontes EMG. CABI Publishing, 373 p.

IŞIKBER AA AND COPLAND MJW. 2002. Effects of various aphid foods on Cycloneda sanguinea. Entomol Exp Appl 102: 93-97.
LAMANA ML AND MILLER JC. 1998. Temperaturedependent development in an Oregon population of Harmonia axyridis (Coleoptera: Coccinallidae). Environ Entomol 27(4): 1001-1005.

LIRA RS AND BATISTA JL. 2006. Aspectos biológicos de Chrysoperla externa alimentados com pulgões da ervadoce. Rev Biol Ciênc Terra 6(2): 20-35.

LÖVEI GL, ANDOW DA AND ARPAIA S. 2009. Transgenic insecticidal crops and natural enemies: a detailed review of laboratory studies. Environ. Entomol. 38: 293-306.

MATOS B AND OBRYCKI JJ. 2006. Prey suitability of Galerucella calmariensis L. (Coleoptera: Chrysomelidae) and Myzus lythri (Schrank) (Homoptera: Aphididae) for development of three predatory species. Environ Entomol 35(2): 345-350.

MURATA AT, CAETANO AC, BORTOLI AS AND BRITO CH. 2006. Capacidade de consumo de Chrysoperla externa (Hagen, 1861) (Neuroptera: Chrysopidae) em diferentes presas. Caatinga 19(3): 304-309.

PAULA DP, ANDOW DA, BELLINATI A, TIMBÓ RV, SOUZA LM, PIRES CSS AND SUJII ER. 2015. Limitations in dose-response and surrogate species methodologies for risk assessment of Cry toxins on arthropod natural enemies. Ecotoxicology 25(3): 601-607.

ROMEIS J, MEISSLE M AND BIGLER F. 2006. Transgenic crops expressing Bacillus thuringiensis toxins and biological control. Nat Biotech 24: 63-71.

ROMEIS J et al. 2008. Assessment of risk of insect-resistant transgenic crops to non-target arthropods. Nat. Biotech. 26: 203-208.

SANTA-CECÍLIA LVC, GONÇALVES-GERVÁSIO RCR, TÔRRES RMS AND NASCIMENTO FB. 2001. Aspectos biológicos e consumo alimentar de larvas de Cycloneda sanguinea (Linnaeus, 1763) (Coleoptera: Coccinelidae) alimentadas com Schizaphis graminum (Rondani, 1852) (Hemiptera: Aphididae). Ciênc Agrotec 25(6): 1273-1278.

SCHLICK-SOUZA EC, TOSCANO LC, SOUZASCHLICK GD, MARUYAMA WI AND PERES AJA. 2011. Desenvolvimento larval de Chrysoperla externa alimentada com Aphis gossypii provenientes de três cultivares de algodoeiro. Agrarian 4(13): 182-188.

SOUZA LM, BELINATTI AR, PAGANELLA MB, PAULA DP, PIRES CSS AND SUJII ER. 2013. Desenvolvimento de dieta artificial para Cycloneda sanguinea (Coleoptera: Coccinellidae). Boletim de Pesquisa e Desenvolvimento, 294, 18 p.

STATHAS GJ, ELIOPOULUS PA, KONTODIMAS DC AND GIANNOPAPAS J. 2001. Parameters of reproductivity activity of females of Harmonia axyridis (Coleoptera: Coccinellidae). Eur J Entomol 98: 547-549. 